\title{
Report to Council 1967/68, ACRL
}

JUNE 1968

This year marks the thirtieth anniversary of the establishment of the Association of College and Research libraries as an ALA Division. During this period of time much has been accomplished by the Association's sections and committees, and the year under review is no exception.

The Junior College Libraries Section, through its several committees, has been just as productive this year as it has in the past. The Bibliography Committee has revised and updated the bibliography on junior college libraries originally compiled by Alice Griffith, chairman of the Section. The revision will be published this summer by ACRL. The Committee on Instruction and Use is planning a textbook for library orientation in junior colleges. The Ad Hoc Committee on Instructional Materials Centers has designed an evaluative checklist and prepared a statement on the relationship of the library to instructional materials centers.

Last year's report referred to the Section's submission of a proposal to the J. Morris Jones, World-Book Encyclopedia, ALA Goals Award for the establishment of a Junior College Library Information Center based in the ACRL office. It is a pleasure to report that a grant was approved for this project. With the growing number of junior colleges and the attendant needs of these institutions, the Center has a special raison d'etre. We are particularly fortunate to have secured the part-time services of Peggy Sullivan to direct the Center, which opened March 1. The Special Projects Committee, working with the Center, is continuing in its efforts to promote better communications between the Section and individual libraries and librarians throughout the country. Specifically to this end it has developed the following methods: circulating materials to junior college librarians, providing an opportunity for librarians to send suggestions to the Section, and assisting in gathering materials for the new Center. To strengthen the committee structure, six regional coordinaters have been appointed to establish rapport between junior colleges and the Information Center and to gather pertinent materials for the latter. The Center will thus be equipped to provide guidance in bibliography, materials for orientation programs, special services to faculty and students, budgets, surveys, buildings, federal funds, cooperative programs, standards, and automation.

The Section has been formulating plans for a preconference to be held in St. Louis June
19 to 22 on the theme "Library Services to Vocational-Technical Education Programs in Junior Colleges." Materials, personnel, and communications will be the three major topics of discussion. The ALA Executive Board has approved the Section's proposal for the establishment of demonstration libraries in community colleges, previously approved by the ACRL, Board of Directors. This proposal for which funds are now being sought will involve six community college libraries selected as demonstration centers where excellent programs of library services geared to the specific needs and potentials of colleges can be observed, and hopefully emulated by the many new junior colleges being established each year. Funds are also being sought for the proposal for an "Investigation of Current Practices of the Community College Library as it Relates to the Instructional Program."

The College Libraries Section will sponsor a preconference on non-Western materials for undergraduate collections at the University of Kansas, under the chairmanship of Andre Nitecki who is also chairman of the Section's Committee on Non-Western Resources. African, Asian and Near Eastern resources constitute the areas whose resources are to be discussed.

The Rare Books Section has planned a preconference program on "The Antiquarian Book Trade in the Twentieth Century," to be held in Kansas City on June 20 to 22 under the chairmanship of the Section Chairman, Professor Lawrence S. Thompson of the University of Kentucky. Speakers at this conference will address themselves principally to the antiquarian book trade in Great Britain, France, Germany, Italy, Spain, Scandinavia, and the Low Countries, as well as the United States. After this conference there will be a meeting of the Mississippi Valley regional group of the Bibliographical Society of America. The Rare Books Section has also under advisement a request from a group of manuscript librarians seeking to join this Section. There will be a meeting of this group to pursue the discussion and actions taken at the San Francisco Conference and the Midwinter Meeting in Bal Harbour.

The Subject Specialists Section continues to pursue its request for change in status to that of a division. The ALA Committee on Organization informed the officers of the Section at Midwinter of its unwillingness to create a new ALA division of the type requested. Alternative solutions are still being sought; it is the feeling of the Section that there is validity and promise in its original proposal, despite the 


\section{Save}

\section{TIME \& MONEY}

\section{when ordering}

\section{SERIAL BINDINGS}

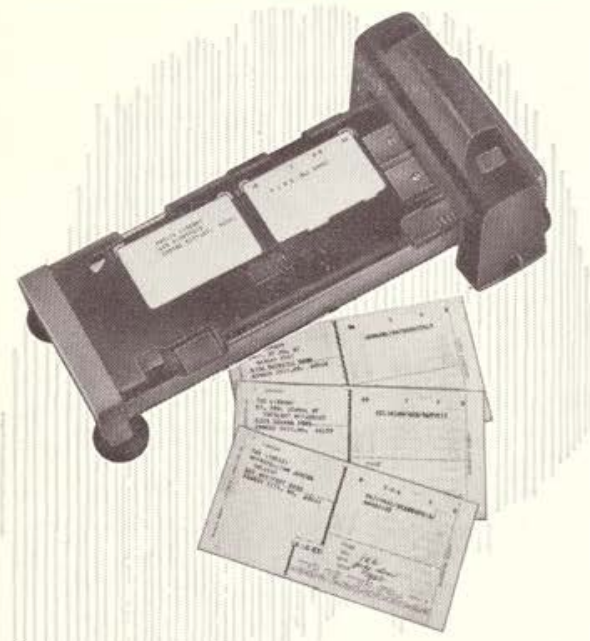

Send today

brochure for describing

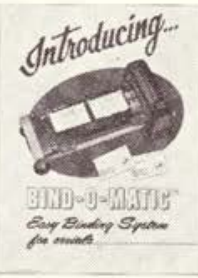

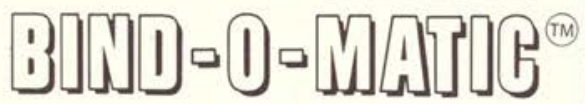

THE AUTOMATIC CODED CARD SYSTEM FOR ORDERING AND RECORD-KEEPING

Exclusively by

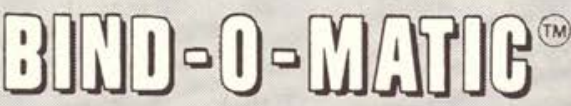

EASY BINDING SYSTEM 1703 Lister

Kansas City, Mo. 64127 understandable fact that the ALA structure cannot now accommodate a group which is characterized as both a type of library and type of activity section.

The Section chairman, Richard Snyder, has worked closely with the subsections, all four of which have been active during the year. The Law and Political Science Subsection has conducted a comprehensive survey of its membership to determine interest and suggestions for the improvement of its programs. A questionnaire was sent to the 650 members and it is hoped that a report will be forthcoming in Kansas City. The Subsection is interested in preparing a guide for the development of legal collections in non-law libraries. Finally, the Subsection is planning a joint meeting at the Kansas City Conference with the Slavic and East European Subsection for the entire membership of the Subject Specialists Section on the topic of Russian librarianship. In addition to this program, the Subject Specialists Section is sponsoring a special meeting with the Music Library Association on the role of the subject specialist in librarianship.

The Slavic and East European Subsection for the past few years has been seeking permission to affiliate with the American Association for the Advancement of Slavic Studies. This proposal was approved by the Board of Directors in San Francisco and by the ALA Council at the Midwinter meeting of 1968. The affiliation will bring about closer cooperation between college and university libraries and faculty members and researchers in the field. It will also make for a better exchange of information between the Subsection and the AAASS which will include pertinent information relative to the work of the Subsection in the former's Newsletter. The Subsection has also been active through a committee planning a survey of Slavic holdings in American and Canadian libraries, some eighteen hundred in number, each having more than one hundred thousand volumes of Slavic materials. The result will be a welcome directory of significant Slavic resources represented by such libraries. The Subsection is also seeking funds to prepare a new edition of its Directory of Libraries in the Fields of Slavic and East European Studies, first published by ALA in 1967 .

The Agriculture and Biological Sciences Subsection is planning a meeting in Kansas City on communications technology and agricultural information. The Subsection is now making plans for a directory of information sources in agriculture and related sciences.

The Art Subsection has planned an interesting meeting for its membership in Kansas City, A member of the Kansas City Art Commission will discuss the Cultural Circulation System in the Heart of America, and there will be a visit to the Nelson Gallery, in addition to a talk 
on Far Eastern books on art-ancient and modern-by the noted art historian, Laurence Sickman. The Art Subsection's Committee on Reprinting of Microfilming Original Source Material has gathered a list of titles as possible candidates which will be discussed in Kansas City.

The University Libraries Section will sponsor a program meeting at the conference in Kansas City on standards for university libraries. This plan is particularly appropriate in view of the ARL-ACRL Committee recently appointed to investigate this area of common concern. The Academic Status Committee of the Section will extend its work as an ad hoc committee through 1968-1969, and in light of demonstrated need it is the division's plan to make this a permanent committee. The committee also plans to edit and publish papers on academic status and related matters, some of which have appeared or will appear in CRL, as an ACRL Monograph.

The Committee on Extension Library Service under the chairmanship of Clover Flanders has had another active year; the committee will present a program at Kansas City with John Osmon of the Brookings Institution as the principal speaker on the topic of urban affairs as they relate to academic libraries.

The Committee on Standards is presently embarked on an examination of the College Library Standards, last revised in 1959, with a view to updating them. The committee has also appointed an Ad Hoc Subcommittee for the Revision of Junior College Library Standards last published in 1960.

As the result of an Ad Hoc Subcommittee on University Library Standards and representation of the Ad Hoc Committee on Relations with ARL to consider possible university library standards held at Boston University last fall and funded by the Council on Library Resources, a joint ARL-ACRL committee, chaired by Dean Robert B. Downs of the University of Illinois, is presently addressing itself to the feasibility of promulgating such standards. It is particularly significant at this time that standards for university libraries should be studied with a view to providing not only the proper base for support by appropriating agencies, but also to reflect the increasing requirements for research materials. Due consideration will also be given to functions of the library, staff, collections, facilities, budget, services, and cooperative programs.

The Committee on Surveys closely allied to and affected by standards is negotiating with the school of library service at Columbia University, with the encouragement of Dean Jack Dalton, for an annual institute on library surveying. The committee also has been seeking approval for the inclusion of apprentice surveyors on survey teams. The committee graciously relinquished its plan for a Kansas
City program meeting to support the ACRL Membership Meeting.

The Committee on Liaison with Accrediting Agencies has been active during the past year in addressing itself and its work to each of the regional accrediting associations. Traditionally the committee has invited to a luncheon the appropriate accrediting agency in the area in which the annual ALA conference is held. This year the committee will change its program format by having a working session instead of a luncheon. The committee's publication Guide to Methods of Library Evaluation will be presented to the ACRL Board for approval at Kansas City. The committee is also considering the revision of the 1957 statement College and University Library Accreditation Standards, ACRL Monograph Number 20. Such a revision, if approved and published, might also include the Guide to Methods of Library Evaluation mentioned above.

At the ACRL Membership Meeting these three committees have agreed to provide representation for reactor panels to the National Advisory Commission on Libraries report, to be presented by Dan Lacy, senior vice president of McGraw-Hill Book Company, and a member of the President's Commission. This plan seems to be particularly appropriate in light of current needs of academic libraries, and also at a time when these three commit-

\section{OTTO HARRASSOWITZ Library Agency \\ WIESBADEN - GERMANY}

Direct service

on all German language

books and periodicals

*

Orders and inquiries are invited on both new and out-of-print material

Farmington Plan agent

for West and East Germany

Please request information about our

blanket order service and dealer's selection program

OTTO HARRASSOWITZ 
tees are actively reacting to these express needs.

The Committee on Community Use of Academic Libraries approved a questionnaire for a survey of the community use of junior college libraries at its midwinter meeting, which has been circulated to junior college libraries. Through the good offices of Barbara LaMont, the Iibrarian at Vassar, the questionnaire will be machine tabulated and an analysis and written report will be compiled by the committee for future publication. Further, the committee is continuing its regional in-depth survey of community use of academic libraries to embrace academic libraries, non-academic libraries, and community users themselves. With the rapid growth of interlibrary cooperative activity throughout the country, and with large numbers of library users having no official ties with academic institutions, there is an understandable interest in the work of this committee.

The National Library Week Committee plans to publish soon a brochure devoted to junior college libraries, on which the committee has been working during the past year. Consideration is now being given to publication clearance and developing an appropriate distribution list.

Although the ACRL Membership Committee was dissolved at the San Francisco meeting, Frances Kennedy remains the ACRL representative on the ALA Membership Committee. Many members have seen the eye-catching

Join the

AMERICAN LIBRARY ASSOCIATION

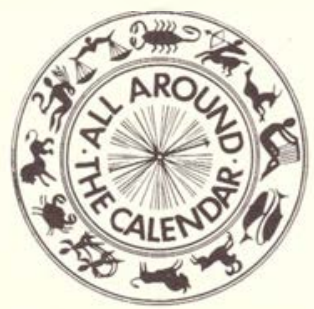

...your Assaciation works for you !

MEMBERSHIP PROMOTION AMERICAM LIBRARY ASSOCIATION SO EAST HURON STREET promotion ads which have appeared in $C R L$ News issues for the past several months. The fact that our membership numbers thirteen thousand-an all time high-is itself indicative of the effectiveness of our representative.

The Committee on Library Services considered the suggestion of Helen Brown, chairman of the Ad Hoc ALA Committee on Instruction in the Use of Libraries, that ACRL and AASL establish a joint committee to consider ways of improving the instruction of teachers in liberal arts colleges in the evaluation, selection, and use of library materials. Accordingly, the presidents of AASL and ACRL have established a joint committee under the chairmanship of James Govan of Swarthmore to pursue this increasingly important subject. The Committee on Library Services, with the cosponsorship of RSD and RTSD, is planning a program for the annual conference on the bibliographer in the academic library, emphasizing the use of bibliographers in reference, in addition to their usual role in acquisitions.

The International Relations Committee, recently established to work with the ALA International Relations Committee, has been active in responding to requests for information from librarians overseas concerning professional opportunities in the United States. The committee is exploring a number of areas: (1) a study of the problem of making the time of service abroad for American librarians a fully valid qualification for promotion in United States libraries, (2) the development of continuing personnel exchanges between sister institutions, and (3) improving understanding and cooperation among many persons working in the international field, (a) development of American collections for international and area studies, and (b) those interested in library development in foreign countries. The International Relations Office has published a directory entitled Who Is Doing What in International Book and Library Programs. A similar directory might be published under the aegis of this committee covering the activities of committees of schools and librarians in this country concerned with the development of American collections of international and area studies. Initial steps in producing this directory have been taken by Warren Tsuneishi of the Library of Congress.

The Audio-Visual Committee has recommended the publication of an $\mathrm{A}-\mathrm{V}$ guide with the chairman of the committee, A. P. Marshall, as the project director. Such a publication would provide a valuable and practical aid for college and junior college librarians in planning and servicing audio-visual materials.

The Grants Committee this year distributed approximately $\$ 60,000$ to ninety academic institutions. Another $\$ 5,000$ was provided for 
the services of committee consultants who gave advice to a dozen emerging institutions. From a total of 289 applications for resources and services, sixty-two grants were approved; of 91 applications for library bureau equipment, fourteen were given; of 14 applications for special grants, twelve received consultant assistance, and seven received an additional grant; of the 12 applications from individual librarians for research grants, funds were available for only two. Principal support for the grants program is provided by the U.S. Steel Foundation with additional contributions from Library Bureau, McGraw-Hill, Olin Mathieson, The H. W. Wilson Foundation, Pitney-Bowes, and Time, Inc. This year, the committee, ACRL officers, and executive secretary spent considerable time and effort in exploring ways and means of enlarging the base of support for this worthwhile program designed to build quality into libraries. This genuine need among the smaller colleges may require outside assistance for fund raising so that the committee can fulfill its functions more effectively.

The Committee on Legislation met at Midwinter with Germaine Krettek of the ALA Washington office to discuss mutual problems, particularly those related to higher education. Members of the committee met with appropri- ate Congressmen, and also have provided a geographically-representative roster of college and university librarians for Miss Krettek's use in a campaign of approaches to Congressmen in furthering legislative action in our behalf. Federal appropriations have been drastically reduced by an economy-minded Congress, so that much of the federal money earmarked for academic libraries is in jeopardy.

The ACRL Publications Committee has concurred in the recommendation that ACRL, AASL, RDS, ISAD, and RTSD join forces in the publication of their journals. The Committee recommended that Mary Falvey be appointed to this office, but with the proviso that adequate professional assistance be assigned to the ACRL office to compensate for the time that Mrs. Falvey presently provides. The committee also supported the value and need of the American Association of Colleges-ACRL for a Newsletter as a medium to inform college presidents of current trends and developments in college libraries. Basil Mitchell has agreed to serve as Editor of the Newsletter and already three publications have been issued. ACRL provides the copy and AAC the funds in this important cooperative venture.

Choice continues to serve the profession and scholars in reviewing current publications. Choice began issuing monthly reviews on cards

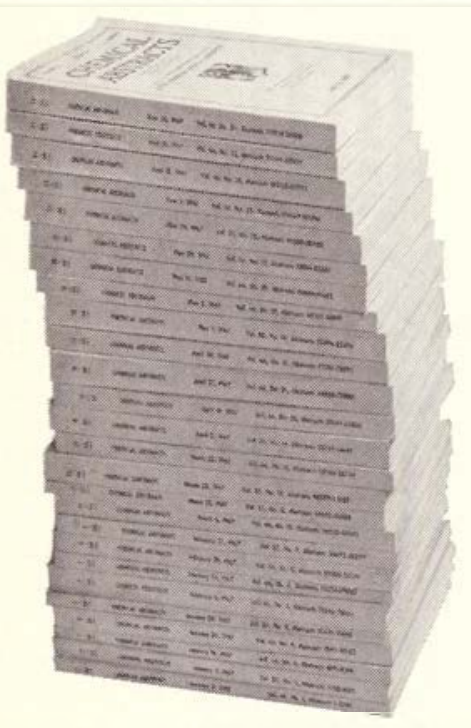

- It you woula like to pack a lot înto a small space, CHEMICAL ABSTRACTS on Microfilm will suit your needs. All 3.8 million abstracts published since 1907 are filmed on $16 \mathrm{~mm}$ microfilm to form a readily accessible file documenting 60 years of chemical progress.

- You can find abstracts quickly and easily, using a variety of microfilm reader-printer equipment. Abstracts may be photocopied at the touch of a button, eliminating the need to make handwritten notes. As a consequence users report a substantial time saving and increasing use of CHEMICAL ABSTRACTS.

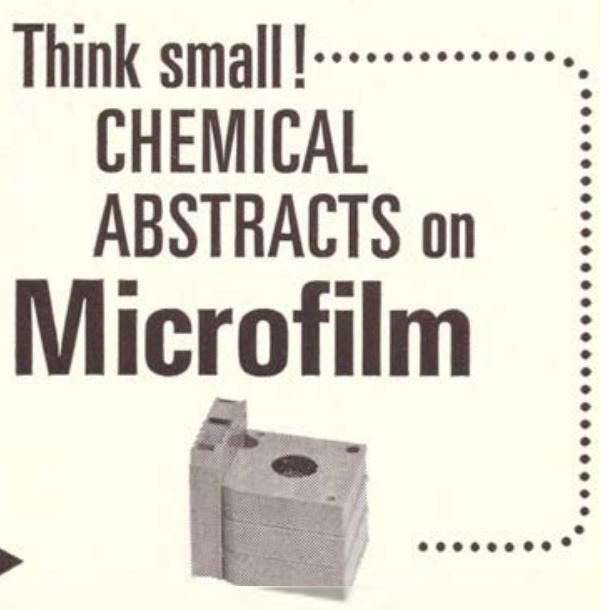

\begin{tabular}{l|l}
$\begin{array}{l}1 \text { Volume (26 } \\
\text { Issues) of } \\
\text { CHEMICAL ABSTRACTS }\end{array}$ & $\begin{array}{l}1 \text { Volume (26 } \\
\text { Issues) of } \\
\text { CHEMICAL ABSTRACTS } \\
\text { on Microfilm }\end{array}$
\end{tabular}

- To find out how you can use this modern information tool in your program, write or telephone E. G. Johnson, Subscriber Information Department (614 293-5022).

\section{CHEMICAL ABSTRACTS SERVICE}

American Chemical Society

Columbus, Ohio 43216 
in March 1968. These are duplicates of the reviews appearing in Choice itself. At the time this program was instituted there were 234 subscribers-a thin margin of support; but two months later there were twenty additional subscribers, thus guaranteeing the financial success of the venture. In advertising revenues, Choice continues to gain. At the present rate of growth, by September 1968 such revenue is estimated at $\$ 104,000$. Subscriptions advanced by almost one thousand, placing Choice at the 5,500 mark; subscription revenue should therefore exceed the budgeted figure by approximately $\$ 13,000$. As a result of this increased activity, an additional 1,000 square feet has been added to Choice's office space. At this time Choice is negotiating with the ALA Publishing Board in its plan to issue supplements to Books for College Libraries under the capable direction of Peter Doiron, Choice editor, and Clifford Fulton, the advertising manager, as well as the Editorial Board. On September 1, 1969, the current Council on Library Resources grant expires; however, Choice's present rate of growth almost certainly insures the established goal of being self sufficient by that date.

David Kaser continues as editor of College and Research Libraries and CRL News-in all, 17 issues a year. In consonance with the growth

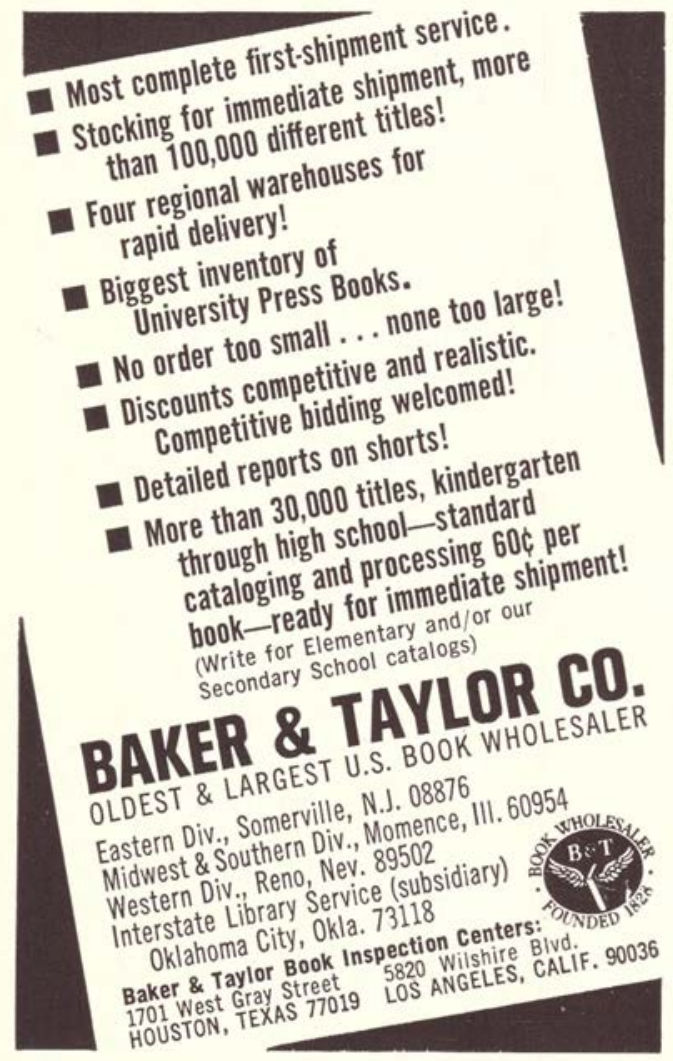

of ACRL, approximately 165,000 copies of CRL were printed in 1966; in 1967 that figure increased to 225,000 copies. Similarly, advertising income increased by nearly $\$ 8,000$. The Publications Officer has managed to keep pace with these increases, and if the proposal to centralize division journals is approved, ACRL will have provided excellent support.

The Editorial Board of the ACRL Monograph Series completed and presented to the ACRL Publications Committee a procedure and policy statement, approved the production of ACRL Monograph 28 (Kinney, The Abbreviated Citation), accepted another title for publication, and is considering three more. As mentioned earlier, the board is considering for publication in the Monograph Series several articles issued by the Academic Status Committee of the University Libraries Section.

The Planning and Action Committee held its annual two-day session at the Joint University Libraries with David Kaser, chairman, in Nashville, Tennessee, in mid-May. A good deal of the discussion centered about the concern ACRL members expressed during the year over the need of improving the status of academic libraries, including tenure, faculty rank, salaries, etc. Among other topics brought before the committee were ACRL's role in the continuing education of its members, the principles of government for academic libraries, and library implications of the changing structure of higher education. All of these matters, many of which necessitate referral to committees or establishment of new ones, will be presented to the ACRL Board for action in Kansas City. Of particular interest to the membership is the projected study on the economic status of librarians, to be conducted by Donald Cameron and funded by the Council on Library Resources. ACRL has agreed to work with Dr. Cameron on this study and a committee will be proposed to the Board for this express purpose.

It has been a privilege and an honor to serve the Association which is the best practical library education being offered today. At times the numbers of sections and committees and individuals seem so large as to defy proper direction by the President and Board of Directors. The full time attention and devotion of the Executive Secretary-George M. Baileyhowever, provides the necessary continuity, Upon the eve of Mr. Bailey's departure for an important library position at York College of the City University of New York, it is both fitting and appropriate to bespeak the ACRL membership's praise to an energetic, competent, and thoroughly professional executive secretary. No ACRL member can better appreciate the truth of this statement than the President. -James Humphry III.

23 May 1968 